\title{
Analyzing the credibility of eword-of-mouth using customer reviews on social media
}

\author{
Alexandra Albon ${ }^{1}$, Patricia Kraft ${ }^{2}$, Carsten Rennhak ${ }^{3 *}$ \\ 1,2 Munich Business School, Munich, Germany \\ ${ }^{3}$ Universität der Bundeswehr, Munich, Germany
}

\section{Keywords \\ Eword-of-mouth Credibility \\ Word-of-mouth \\ Social media}

Received:8 December 2017

Accepted: 5 January 2018

Published: 13 February 2018

\begin{abstract}
This paper aims to identify the key drivers of credibility in eWord-of-Mouth based on a comprehensive literature analysis and a field study. To gather the data, an online questionnaire $(n=161)$ is used. The results demonstrate that credibility is predominantly influenced by source, message, and media credibility. Since social media sources are often anonymous, credibility surrogates need to be identified: this paper gives evidence that expertise/knowhow, style of speech, and logic/structure of message reasoning are perceived as the credibility drivers. Concerning media credibility, ease of navigation/usability and structure were identified as key drivers. Visual elements and interactivity were not identified as significant drivers of media credibility. From a practical perspective, collecting, systematizing, filter, and analyzing positive and negative recommendations is particularly important for firms. Moreover, companies should support consumers in writing high-quality reviews by offering templates.
\end{abstract}

\section{RELEVANCE AND PROBLEM STATEMENT}

Recently, the development of the Internet into an essential means of communication has led to a radical change in existing communication. New forms of channels make it possible to generate, share, and quickly distribute content and provide new options for companies in terms of marketing tools (Ismagilova, Dwivedi, Slade, \& Williams, 2017). One of these forms of communication is Electronic Word of Mouth (eWoM). Traditional WoM is the main source of information behind 20 percent to 50 percent of all purchase decisions (Bughin, Doogan, \& Vetvik, 2010) and, in an online setting as well, strongly influences the customers' attitude towards a product (G.-H. Huang \& Korfiatis, 2015; Ladhari \& Michaud, 2015), brand (Lee, Rodgers, \& Kim, 2009; Wu \& Wang, 2011), or website (Lee et al., 2009). It, therefore, plays a decisive role in influencing a consumer's purchase intent (Beneke, Mill, Naidoo, \& Wickham, 2015; Lin, Wu, Chen, et al., 2013).
A continuously growing number of communication stimuli implemented by companies is accompanied by the consumer's ubiquitous media consumption. This often results in the phenomenon known as information overload. Limited in their capacity to process information, consumers then find themselves compelled to select the many pieces of information that have an impact on them to filter only that which is relevant. One of these selection tools is the credibility of a piece of information (Brandlmaier et al., 2006; Case, Johnson, Andrews, Allard, \& Kelly, 2004; GröppelKlein \& Germelmann, 2009). Many studies underline that credibility significantly impacts the adaptation of eWo M (Qiu \& Li, 2010). Up till now, however, only a few empirical studies have dealt specifically with the individual influences of credibility in the eWo M context (M. Y. Cheung, Luo, Sia, \& Chen, 2009; Lim \& Van Der Heide, 2014; Lis, 2013). To help clarify how companies can derive maximum marketing benefit from eWoM, this study analyses the individual influ-

\footnotetext{
${ }^{*}$ Corresponding author: Carsten Rennhak

†Email: Carsten.rennhak@unibw.de
} 
ence factors of eWoM credibility from both a theoretical and empirical perspective.

\section{THEORETICAL BASIS WoM}

Arndt (1967, p. 3) defines WoM as "oral, person-to-person communication between a recipient and a communicator whom the recipient perceives as non-commercial, regarding a brand, a product or a service". Arndt (1967), thus, emphasises four key characteristics of traditional WoM and postulates that it must involve personal communication, oral transfer, a non-commercial sender, and a product, brand, or service as the subject of communication (Lis \& Korchmar, 2012).

\section{EWOM}

In the online context, eWoM can be defined as "any positive or negative statement made by potential, actual, or former customers about a product or company which is made available to a multitude of people and institutions via the Internet" (Hennig-Thurau, Gwinner, Walsh, \& Gremler, 2004). eWoM communications are characterised by enormous range, communication partner anonymity, lack of privacy, weak social ties between individual users, and no guarantee of consistency regarding the respective information on the Internet (Eisingerich, Chun, Liu, Jia, \& Bell, 2015; Ismagilova et al., 2017).

An analysis of eWoM studies shows three current key research areas: the motivation to deliver and receive eWoM, the power of persuasion of eWoM, and the general effect of eWoM. Regarding the active delivery of eWoM, these studies reveal that altruism is a key motive for participation, closely followed by the communicator's desire to present him or herself and relieve emotive tensions (Berger, 2014; Hennig-Thurau \& Hansen, 2001; Rathore, 2015). For the most part, eWoM is welcomed because of the opportunity it provides to clarify ambiguities concerning products quickly and efficiently on online feedback platforms (Godes \& Mayzlin, 2004; Murray, 1991). This significantly reduces the perceived risk of mispurchasing when making purchase decisions (Ha, 2002; Visser, 2016).

Regarding the persuasive power of eWoM, a distinction is made between credibility and usefulness for the recipient. A recommendation is seen as helpful and useful when it functions as a supportive tool for the consumer to make a buying decision. As part of this process, convincing reviews are meant to influence consumer attitudes and purchase intent (Davis, 1989; Jeong \& Koo, 2015). An assessment of the extent to which an eWoM message is useful depends on attributes that can be ascribed to either the communicator, the medium, or even the message itself and covers factors, such as the rankings, quality, and quantity of the information communicated and the nature of the platform (Ismagilova et al., 2017).

The last research area deals with the effect of eWoM communication. In this context, it has been revealed that eWoM substantially influences the adaptation of information, consumers' attitude, and purchase intent (Baek, Ahn, \& Oh, 2014; Beneke et al., 2015; M. Y. Cheung, Luo, Sia, \& Chen, 2007; G.-H. Huang \& Korfiatis, 2015; Ismagilova et al., 2017; Wang, Teo, \& Wei, 2015).

\section{Communication in the eWoM Context}

Based on key findings from the previous mass communication research, the communication process can be subdivided into individual research areas (Schenk, 2007). In the eWoM context, this translates into the following key communication components: the communicator of a message, the communication content, the communication channel, the recipient, the context, and the communication effect. In eWoM research, the effect of eWoM is classified as a dependent variable (C. M. Cheung \& Thadani, 2012), while the recipient and the situational context are classified as moderating variables. Within the eWoM communication process, the communicator, message, and medium are the only variables that are un-derstood to be independent (C. M. Cheung \& Thadani, 2012; Doh \& Hwang, 2009). They are the subject of all further analyses of this paper.

\section{Credibility}

Although various scientific disciplines deal with the research topic of credibility, certain parameters apply to all disciplines: communication, relevance, and uncertainty (Eisend, 2003). In empirical research, credibility is understood as a multidimensional construct. The most decisive papers in this respect are those of Hovland and Weiss (1951) in the 1940s. The authors describe credibility through the dimensions of competence and trustworthiness (Hovland \& Weiss, 1951; Schenk, 2007).

From a theoretical perspective, the recipient-centred approach has become particularly well-established for clearly defining credibility. Hence, credibility can be defined as "a characteristic that is ascribed to people, organisations or their communicative products (oral or written texts, audiovisual illustrations) by somebody (recipients) with regard to something (events, circumstances, etc.)" Bentele and Seidenglanz (2015, p. 412).

While credibility research can be subdivided into two key 
research areas (Eisend, 2003), this study focuses on credibility assessment. It investigates the question of which factors the recipient uses to determine an object's credibility (Nawratil, 2013) and comprises two further research areas: credibility diagnosis and credibility attribution. The latter forms the basis for this study and analyses the observations made by the recipient that determine his or her credibility judgement (Eisend, 2003). Credibility assessment can be either behaviour-oriented, content-oriented, or source or context-oriented (Nawratil, 2013), the latter covered by the most studies being the most extensive area of credibility research and seemingly extremely relevant, particularly with regard to the eWoM communication process components. Source and context-oriented analysis examines the characteristics of the communicator, message, medium, context, and recipient (Eisend, 2003; Nawratil, 2013). Regarding the independent variables of the eWoM communication process, results have shown that for the communicator, it is mainly the properties of competence, trustworthiness, similari-ty, and physical attractiveness; for the message style, the language, contents, and structure of the message; and, for the medium, the type of medium, the accuracy with which the information is communicated, and the visual presentation that have an impact on perceived credibility (Bentele \& Seidenglanz, 2015; Carbone, 1975; Eisend, 2003; Ohanian, 1990; Robinson \& Kohut, 1988).

\section{CREDIBILITY IN EWOM COMMUNICATION Current Status of Research on eWoM Credibility}

To date, only a few studies explicitly investigating the credibility of eWoM have been published (M. Y. Cheung et al., 2007; Lim \& Van Der Heide, 2014; Lis, 2013; Mackiewicz, 2008; Oetting, 2010). Many of these focus only on the subject in a secondary role, as part of research on the general effect of eWoM (Hennig-Thurau et al., 2004; Oetting, 2010; Walsh \& Mitchell, 2010) and on product success (Chevalier \& Mayzlin, 2006) or as part of the analysis of incentives for eWoM (Hennig-Thurau et al., 2004; Hung \& Li, 2007).

The theoretical basis of both the eWoM communication process and source- and con-text-oriented credibility assessment considers the communicator, the message, and the medium as relevant determinants. In credibility research in the eWoM context, studies on communicator credibility dominate (M. Y. Cheung et al., 2007; Lis, 2013; Mackiewicz, 2008; Steffes \& Burgee, 2009), followed closely by studies regarding the individual eWoM message (C. M. Cheung, Lee, \& Rabjohn, 2008).

\section{Communicator Characteristics Expertise}

Studies on the recipient's credibility assessment in an offline context have identified the dimensions of competence and trustworthiness as relevant. Ohanian (1990, p. 44) defines expertise as "the extent to which a person is perceived to possess knowledge, skills or experience and, thereby, is considered to provide accurate information"; that is, it describes the communicator's expert knowledge, professionalism, and experience with respect to a specific product or service of interest to the recipient.

The analysis of eWoM in online communities, however, has also shown that recipients often base their decisions not so much on expert knowledge but, rather, on the number of reviews submitted by other participants. According to (J.-H. Huang \& Chen, 2006), however, a lack of expertise on the part of the communicator can partly be compensated in purchase decisions with a higher level of trustworthiness.

\section{Trustworthiness}

Trustworthiness refers to the level of trust a recipient ascribes to the communicator of an eWoM message (Ismagilova et al., 2017). The credibility of a message submitted by a communicator who seems trustworthy is mistrusted far more rarely than the credibility of sources that signal a low level of trustworthiness from the outset. Various studies show that trustworthiness has a positive effect on perceived credibility (C. M. Cheung \& Thadani, 2012; Lee et al., 2009; Lis, 2013; Mackiewicz, 2008). Trust is a key factor in recipient participation in virtual communities and on virtual platforms (Reichelt, 2013) and can, therefore, be understood as a criterion for credibility.

\section{Homophily}

In this context, homophily describes the degree of similarity between the communica-tor and the recipient and can refer to criteria, such as values and attitudes, social status, and education and other criteria, according to which two communication partners can be compared (Rogers, 2010). WoM research has established that homophily increases the communicator's influence and that the recipient takes homophilic sources into consideration much more frequently than other sources of information. Some studies also add to the traditional understanding of homophily the decisive criterion that homophily is to be understood not only as a similarity but also as an emotional bond between the communication partners, based on features, such as similar life-styles, preferences, and tastes e.g., (Lis \& Korchmar, 2012). 


\section{Message Characteristics}

\section{Type of message}

The components of an eWoM message have an impact on perceived credibility (M. Y. Cheung et al., 2009; Doh \& Hwang, 2009). A particularly relevant feature in this context is the nature of the message (Ismagilova et al., 2017). This encompasses the differentiation between one and twosided messages, on one hand, and the distinction between positive and negative messages, on the other. One-sided messages are characterized by either only positive or only negative content, while two-sided messages provide the recipient with both positive and negative message elements (Küster, 2012).

The correct proportion between positive and negative message elements increases perceived credibility and that a small number of negative elements amongst many positive elements can achieve an authentic and credible effect (Doh \& Hwang, 2009). Generally, in the eWoM credibility context, two-sided messages are said to be more credible more often than one-sided messages (Jensen, Averbeck, Zhang, \& Wright, 2013) and that, as part of the analysis of onesided messages, many empirical findings indicate that primarily, negative recommendations achieve a greater effect than positive recommendations (Bae \& Lee, 2011; Ismagilova et al., 2017).

\section{Argument Quality}

The quality of the argument of an eWoM message sometimes has the greatest effect on perceived credibility (Lis \& Korchmar, 2012). The terms argument strength, argument quality, and information quality are often used synonymously and, in terms of the perceived persuasive strength of an informational message, describe the same aspect (Bhattacherjee \& Sanford, 2006; Lis \& Korchmar, 2012). Teng, Wei Khong, Wei Goh, and Yee Loong Chong (2014) have established a positive connection between the argument strength of an eWoM message and its perceived credibility. The effect an argument has on a recipient depends on four dimensions: the relevance of the information from the recipient's perspective, the topicality of the message, the accuracy of the information communicated, and the information's comprehensiveness (Ismagilova et al., 2017).

\section{Medium Characteristics Website/platform presentation}

In research on website credibility, that is, the study of factors that determine the credibility of the medium, various approaches can be identified. The most important is probably the study of what is referred to as surface credibility. Surface credibility re-fers to the credibility that is perceived based on an assessment of a website's initial superficial impression (Fogg \& Tseng, 1999). Wathen and Burkell (2002) postulate that a website's surface credibility is probably the most important aspect of the recipient's online credibility assessment because it determines whether further credibility criteria are to be studied in a further phase.

\section{Type of platform}

Part of credibility research examines the impact of social media as a communication channel on the perceived credibility of eWoM. The use of social media as a communication channel significantly increases the perceived credibility and usefulness of eWoM communication and ultimately leads to the recipient changing his or her attitude and adapting some of the information. The possibility of interacting with other members within social networks is the main reason for the high level of perceived credibility (Hajli, 2018; Nugraha \& Indrawati, 2017).

\section{EMPIRICAL STUDY}

\section{Structure of the Study, Method, and Procedure}

A theoretical elaboration of the current status of research shows that communicator, message, and medium characteristics affect the perceived credibility of eWoM. The following considerations examine these characteristics from an empirical perspective. To recapitulate, the communicator's expertise and trustworthiness and the homophily between the communicator and the recipient have a positive effect on credibility. 
TABLE 1. Hypotheses on the effect of the communicator

\begin{tabular}{ll}
\hline \hline H1 & Communicator characteristics increase the perceived credibility of eWoM \\
\hline \hline Hla & The greater the communicator's perceived expertise, the greater the perceived credibility of eWoM \\
Hlb & The greater the communicator's perceived trustworthiness, the greater the perceived credibility of eWoM \\
Hlc & The greater the perceived homophily, the higher the perceived credibility of eWoM \\
\hline
\end{tabular}

TABLE 2. Hypotheses on the effect of the message

\begin{tabular}{ll}
\hline \hline H2 & Message characteristics increase the perceived credibility of eWoM \\
\hline \hline H2a & Two-sided eWoM messages are perceived as more credible than one-sided eWoM messages \\
H2b & Negative eWoM messages are perceived as more credible than positive eWoM messages \\
H2c & The greater the perceived relevance of an eWoM message, the higher the perceived credibility of eWoM \\
H2d & The greater the perceived topicality of an eWoM message, the greater the perceived credibility of eWoM \\
H2e & The greater the perceived accuracy of an eWoM message, the greater the perceived credibility of eWoM \\
H2f & The greater the perceived information comprehensiveness of an eWoM message, the greater the perceived \\
& credibility of eWoM \\
\hline \hline
\end{tabular}

TABLE 3. Hypotheses on the effect of the medium

\begin{tabular}{ll}
\hline \hline H3 & The medium's characteristics increase the perceived credibility of eWoM \\
\hline \hline H3a & The better the perceived visual presentation of the medium, the greater the perceived credibility of eWoM \\
H3b & The greater the perceived simplicity of navigation and structure within the medium, the greater the perceived \\
& credibility of eWoM \\
H3c & The greater the perceived social interactivity in social networks, the greater the perceived credibility of eWoM \\
\hline
\end{tabular}

Based on the findings above, in this empirical study, it is necessary to look at the effects of the communicator, mes- sage, and medium on the perceived credibility as independent variables. Figure 1 illustrates this study's structure.

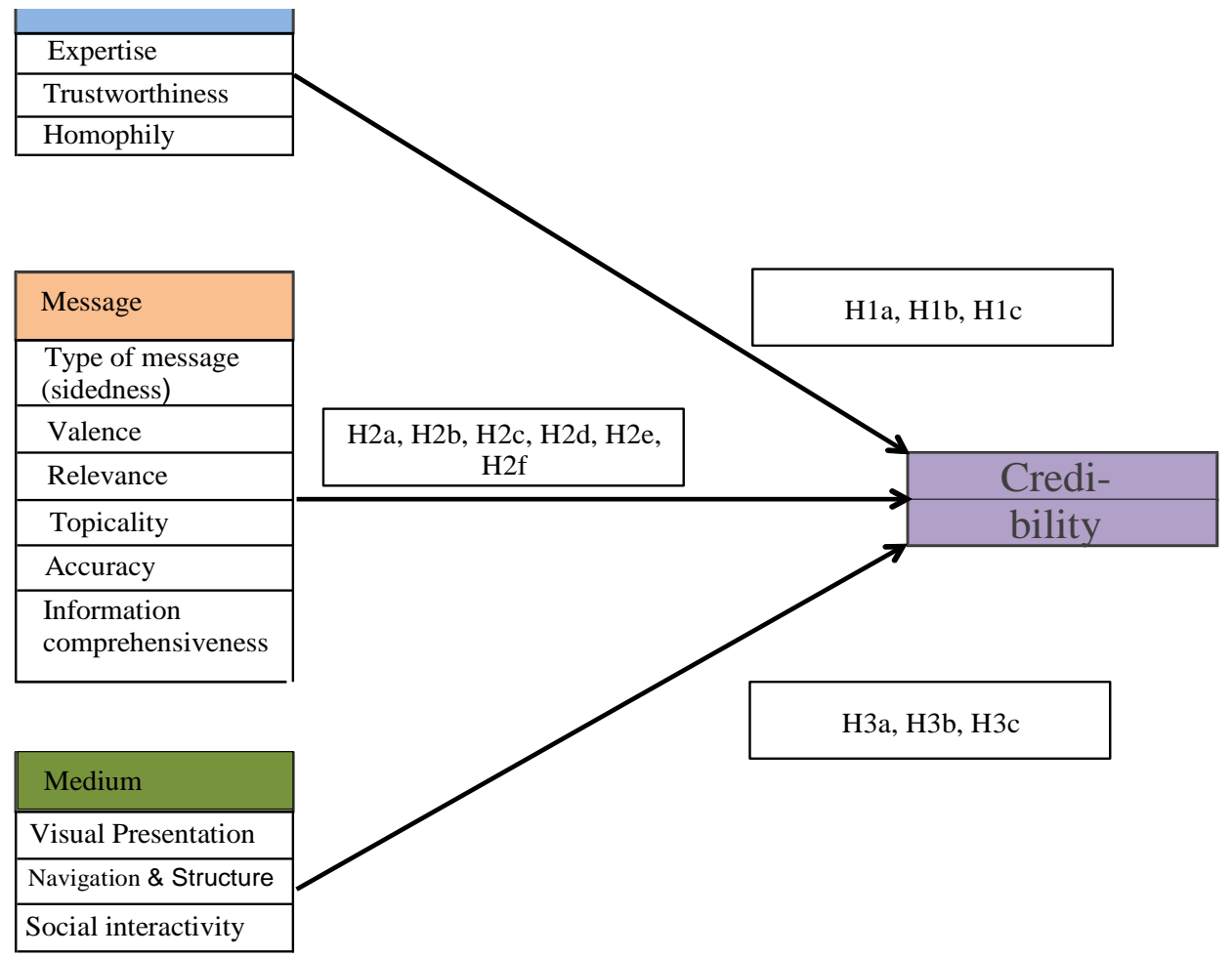

FIGURE 1. Study structure - Analysis of the credibility of eWoM 
To verify the coherences postulated in the theory, crosssectional data from a web survey were examined (Schnell,
Hill, \& Esser, 1999). All the scales for operationalising the variables were taken from other studies and adapted.

TABLE 4. Operationalisation of the independent variables

\begin{tabular}{|c|c|c|c|c|c|}
\hline \multirow{2}{*}{$\begin{array}{l}\begin{array}{l}\text { Subject of } \\
\text { the study }\end{array} \\
\text { Communi- } \\
\text { cator }\end{array}$} & \multirow{2}{*}{$\begin{array}{c}\text { Variable } \\
\text { Expertise }\end{array}$} & \multirow{2}{*}{$\begin{array}{l}\text { Item } \\
\text { expl }\end{array}$} & \multicolumn{2}{|c|}{ Determinant } & \multirow{2}{*}{$\begin{array}{l}\text { Source } \\
\text { Reichelt } \\
\text { (2013) }\end{array}$} \\
\hline & & & $\begin{array}{l}\text { The writer of a re- } \\
\text { view/recommenda- } \\
\text { tion should... }\end{array}$ & $\begin{array}{l}\text {...be very well informed about } \\
\text { the product being validated/ } \\
\text { recommended. }\end{array}$ & \\
\hline & & $\exp 2$ & & $\begin{array}{l}\text {...have had much experience } \\
\text { with the product in question. }\end{array}$ & $\begin{array}{l}\text { Reichelt } \\
\text { (2013) }\end{array}$ \\
\hline & & $\exp 3$ & & $\begin{array}{l}\text {...have a positive feeling about } \\
\text { the product. }\end{array}$ & $\begin{array}{l}\text { Reichelt } \\
\text { (2013) }\end{array}$ \\
\hline & $\begin{array}{l}\text { Trustworthi- } \\
\text { ness }\end{array}$ & tru1 & $\begin{array}{l}\text { The writer of a re- } \\
\text { view/recommenda- } \\
\text { tion should... }\end{array}$ & ...be trustworthy. & $\begin{array}{l}\text { Reichelt } \\
\text { (2013) }\end{array}$ \\
\hline & & tru2 & & $\begin{array}{l}\text {...submit honest reviews and } \\
\text { recommendations. }\end{array}$ & $\begin{array}{l}\text { Reichelt } \\
\text { (2013) }\end{array}$ \\
\hline & & tru3 & & ...be trustworthy. & $\begin{array}{l}\text { Reichelt } \\
\text { (2013) }\end{array}$ \\
\hline & & tru4 & & ...be reliable. & $\begin{array}{l}\text { Reichelt } \\
\text { (2013) }\end{array}$ \\
\hline & Homophily & hom1 & $\begin{array}{l}\text { The writer of a re- } \\
\text { view/recommenda- } \\
\text { tion should... }\end{array}$ & $\begin{array}{l}\text {...have opinions and beliefs simi- } \\
\text { lar to mine. }\end{array}$ & $\begin{array}{l}\text { Reichelt } \\
\text { (2013) }\end{array}$ \\
\hline & & hom2 & & ...be quite similar to me. & $\begin{array}{l}\text { Reichelt } \\
\text { (2013) }\end{array}$ \\
\hline & & hom3 & & $\begin{array}{l}\text {...have tastes and preferences } \\
\text { similar to mine. }\end{array}$ & $\begin{array}{l}\text { Reichelt } \\
\text { (2013) }\end{array}$ \\
\hline \multirow[t]{8}{*}{ Message } & Message type & sidl & $\begin{array}{l}\text { A review/recommen- } \\
\text { dation should... }\end{array}$ & $\begin{array}{l}\text {...cover both positive and nega- } \\
\text { tive aspects of the product. }\end{array}$ & $\begin{array}{l}\text { M. Y. Cheung et } \\
\text { al. (2009) }\end{array}$ \\
\hline & & $\operatorname{sid} 2$ & & $\begin{array}{l}\text {...cover either only positive or } \\
\text { only negative aspects of the } \\
\text { product. }\end{array}$ & $\begin{array}{l}\text { M. Y. Cheung et } \\
\text { al. (2009) }\end{array}$ \\
\hline & Valence & val1 & $\begin{array}{l}\text { A review/recommen- } \\
\text { dation should... }\end{array}$ & $\begin{array}{l}\text {...on the whole cover mainly the } \\
\text { positive aspects of the product. }\end{array}$ & $\begin{array}{l}\text { M. Y. Cheung et } \\
\text { al. (2009) }\end{array}$ \\
\hline & & val 2 & & $\begin{array}{l}\text {...on the whole cover mainly the } \\
\text { negative aspects of the product. }\end{array}$ & $\begin{array}{l}\text { M. Y. Cheung et } \\
\text { al. (2009) }\end{array}$ \\
\hline & Relevance & rel1 & $\begin{array}{l}\text { The content of a rec- } \\
\text { ommendation/review } \\
\text { should... }\end{array}$ & ...be useful for me. & $\begin{array}{l}\text { Lee et al. } \\
(2009)\end{array}$ \\
\hline & & rel2 & & ...be relevant to me. & $\begin{array}{l}\text { Lee et al. } \\
(2009)\end{array}$ \\
\hline & & rel3 & & ...suit my personal situation. & $\begin{array}{l}\text { Lee et al. } \\
(2009)\end{array}$ \\
\hline & & rel4 & & $\begin{array}{l}\text {...be applicable to my personal } \\
\text { situation. }\end{array}$ & $\begin{array}{l}\text { Lee et al. } \\
(2009)\end{array}$ \\
\hline
\end{tabular}


Table 4 Continuee

\begin{tabular}{|c|c|c|c|c|c|}
\hline \multirow{2}{*}{$\begin{array}{l}\text { Subject of } \\
\text { the study }\end{array}$} & \multirow{2}{*}{$\begin{array}{c}\text { Variable } \\
\text { Topicality }\end{array}$} & \multirow{2}{*}{$\begin{array}{l}\text { Item } \\
\text { top1 }\end{array}$} & \multicolumn{2}{|c|}{ Determinant } & \multirow{2}{*}{$\begin{array}{l}\text { Source } \\
\text { C. M. Cheung } \\
\text { et al. (2008) }\end{array}$} \\
\hline & & & $\begin{array}{l}\text { The content of a rec- } \\
\text { ommendation/review } \\
\text { should... }\end{array}$ & ...be up-to-date. & \\
\hline & & top2 & & ...be contemporary. & $\begin{array}{l}\text { C. M. Cheung } \\
\text { et al. (2008) }\end{array}$ \\
\hline & & top3 & & ...bring me up-to-date. & $\begin{array}{l}\text { C. M. Cheung } \\
\text { et al. (2008) }\end{array}$ \\
\hline & Accuracy & accl & $\begin{array}{l}\text { The content of a rec- } \\
\text { ommendation/review } \\
\text { should... }\end{array}$ & ...be accurate. & $\begin{array}{l}\text { C. M. Cheung } \\
\text { et al. (2008) }\end{array}$ \\
\hline & & acc2 & & ...be correct. & $\begin{array}{l}\text { C. M. Cheung } \\
\text { et al. (2008) }\end{array}$ \\
\hline & & acc3 & & ...be reliable. & $\begin{array}{l}\text { C. M. Cheung } \\
\text { et al. (2008) }\end{array}$ \\
\hline \multirow[t]{10}{*}{ Medium } & $\begin{array}{l}\text { Visual } \\
\text { presentation }\end{array}$ & vis1 & $\begin{array}{l}\text { It is particularly impor- } \\
\text { tant for me that... }\end{array}$ & ...the website looks great. & $\begin{array}{l}\text { Montoya- } \\
\text { Weiss, Voss, } \\
\text { and Grewal } \\
\text { (2003) }\end{array}$ \\
\hline & & vis2 & & $\begin{array}{l}\text {...the website makes an appealing } \\
\text { impression on me. }\end{array}$ & $\begin{array}{l}\text { Montoya- } \\
\text { Weiss et al. } \\
(2003)\end{array}$ \\
\hline & & vis3 & & $\begin{array}{l}\text {...the website contains great } \\
\text { graphic illustrations. }\end{array}$ & $\begin{array}{l}\text { Montoya- } \\
\text { Weiss et al. } \\
(2003)\end{array}$ \\
\hline & $\begin{array}{l}\text { Navigation \& } \\
\text { structure }\end{array}$ & nav1 & $\begin{array}{l}\text { It is particularly impor- } \\
\text { tant for me that... }\end{array}$ & $\begin{array}{l}\text {...it be easy to find the information } \\
\text { I need on the website. }\end{array}$ & $\begin{array}{l}\text { Montoya- } \\
\text { Weiss et al. } \\
\text { (2003) }\end{array}$ \\
\hline & & nav2 & & $\begin{array}{l}\text {...the website contains a clear } \\
\text { breakdown that lists all the topics } \\
\text { it covers. }\end{array}$ & $\begin{array}{l}\text { Montoya- } \\
\text { Weiss et al. } \\
\text { (2003) }\end{array}$ \\
\hline & & nav3 & & $\begin{array}{l}\text {...it be easy to navigate freely on } \\
\text { the website. }\end{array}$ & $\begin{array}{l}\text { Montoya- } \\
\text { Weiss et al. } \\
(2003)\end{array}$ \\
\hline & & nav4 & & $\begin{array}{l}\text {...the website has a structure that } \\
\text { is logically structured and easy to } \\
\text { follow. }\end{array}$ & $\begin{array}{l}\text { Montoya- } \\
\text { Weiss et al. } \\
\text { (2003) }\end{array}$ \\
\hline & $\begin{array}{l}\text { Social } \\
\text { Interactivity }\end{array}$ & rel1 & In social networks... & $\begin{array}{l}\text {...I ask my friends for tips and ad- } \\
\text { vice before I actually decide to } \\
\text { purchase something. }\end{array}$ & Hajli (2018) \\
\hline & & rel2 & & $\begin{array}{l}\text {...I am willing to share with my } \\
\text { friends my own experiences with } \\
\text { products and services in the form } \\
\text { of reviews and recommendations. }\end{array}$ & Hajli (2018) \\
\hline & & rel3 & & $\begin{array}{l}\text {...I am willing to recommend to my } \\
\text { friends products and services that } \\
\text { are worth purchasing. }\end{array}$ & Hajli (2018) \\
\hline
\end{tabular}


TABLE 5. Operationalisation of the dependent variables

\begin{tabular}{|c|c|c|c|c|c|}
\hline \multirow{2}{*}{$\begin{array}{l}\begin{array}{l}\text { Subject of } \\
\text { the study }\end{array} \\
\text { Credibility }\end{array}$} & \multirow{2}{*}{$\begin{array}{c}\text { Variable } \\
\text { Credibility }\end{array}$} & \multirow{2}{*}{$\begin{array}{l}\text { Item } \\
\text { cred1 }\end{array}$} & \multicolumn{2}{|c|}{ Determinant } & \multirow{2}{*}{$\begin{array}{l}\text { Source } \\
\text { M. Y. Cheung } \\
\text { et al. (2009) }\end{array}$} \\
\hline & & & $\begin{array}{l}\text { For me, it is very impor- } \\
\text { tant that a review/recom- } \\
\text { mendation... }\end{array}$ & $\begin{array}{l}\text {...be a true representation of the } \\
\text { facts. }\end{array}$ & \\
\hline & & cred2 & & ...be precise. & $\begin{array}{l}\text { M. Y. Cheung } \\
\text { et al. (2009) }\end{array}$ \\
\hline & & cred3 & & ...be credible. & $\begin{array}{l}\text { M. Y. Cheung } \\
\text { et al. (2009) }\end{array}$ \\
\hline
\end{tabular}

TABLE 6. Fornell-Larcker criterion

\begin{tabular}{|c|c|c|c|c|c|c|c|c|c|c|c|c|c|}
\hline & TOP & CRED & EXP & ACC & HOM & $\mathrm{COM}$ & P NAV & REL & SID & SOC & VAL & VER & VIS \\
\hline $\begin{array}{l}\text { Topicality } \\
\text { (TOP) }\end{array}$ & 0.913 & & & & & & & & & & & & \\
\hline $\begin{array}{l}\text { Credibility } \\
\text { (CRED) }\end{array}$ & 0.678 & 0.914 & & & & & & & & & & & \\
\hline $\begin{array}{l}\text { Expertise } \\
\text { (EXP) }\end{array}$ & 0.59 & 0.788 & 0.849 & & & & & & & & & & \\
\hline $\begin{array}{l}\text { Accuracy } \\
\text { (ACC) }\end{array}$ & 0.43 & 0.487 & 0.462 & 0.906 & & & & & & & & & \\
\hline $\begin{array}{l}\text { Homophily } \\
\text { (HOM) }\end{array}$ & 0.601 & 0.812 & 0.612 & 0.398 & 0.875 & & & & & & & & \\
\hline $\begin{array}{l}\text { Inf compre- } \\
\text { hensiveness } \\
\text { (COMP) }\end{array}$ & 0.716 & 0.79 & 0.717 & 0.507 & 0.726 & 0.881 & & & & & & & \\
\hline $\begin{array}{l}\text { Nav. \& struc- } \\
\text { ture (NAV) }\end{array}$ & 0.589 & 0.676 & 0.64 & 0.324 & 0.596 & 0.649 & 0.867 & & & & & & \\
\hline $\begin{array}{l}\text { Relevance } \\
\text { (REL) }\end{array}$ & 0.545 & 0.644 & 0.566 & 0.326 & 0.597 & 0.585 & 0.444 & 0.921 & & & & & \\
\hline $\begin{array}{l}\text { Sidedness } \\
\text { (SID) }\end{array}$ & 0.347 & 0.482 & 0.57 & 0.418 & 0.468 & 0.45 & 0.283 & 0.34 & 0.881 & & & & \\
\hline Soc. int. (SOC) & -0.1 & -0.05 & -0.08 & -0.18 & -0.11 & -0.112 & -0.05 & -0.15 & -0.19 & 0.913 & & & \\
\hline Valence (VAL) & 0.232 & 0.185 & 0.19 & 0.212 & 0.217 & 0.202 & 0.209 & 0.235 & 0.187 & -0.18 & 0.877 & & \\
\hline $\begin{array}{l}\text { Trustworthi- } \\
\text { ness (TRU) }\end{array}$ & 0.376 & 0.55 & 0.443 & 0.32 & 0.496 & 0.478 & 0.465 & 0.276 & 0.314 & 0.114 & 0.087 & 0.881 & \\
\hline $\begin{array}{l}\text { Visual struc- } \\
\text { ture (VIS) }\end{array}$ & 0.264 & 0.322 & 0.279 & 0.178 & 0.303 & 0.387 & 0.438 & 0.191 & 0.218 & -0.01 & 0.055 & 0.273 & 0.952 \\
\hline
\end{tabular}

The average variance of each construct is greater than its squared correlations with the other constructs. Vice versa, the root of the average variance of each construct is greater than its correlations with the other constructs

The questionnaire was distributed via social networks, with $n=161$ respondents. The questionnaire got distributed through social networks and was divided into three main areas: in the beginning section, questions were asked about the general usage of social networks, after which the variables were measured and the test participants were asked demographic questions. As this study aims to analyse cred- ibility of eWoM on social media, only survey participants with access to social media have been taken into consideration (filter question). With the help of a pre-test, a formal and content-related test as well as an initial item and scale analysis were carried out. With the exception of a few ambiguities, the questionnaire was rated by the test persons as comprehensible and the measuring quality of the indi- 
vidual scales was classified as very good. Two items with a relatively low selectivity value were removed to improve the Cronbach's alpha values of the respective scales. The sample for the main study was generated by means of an arbitrary selection process. Results based on this sampling technique need to be handled with care as this convenient sample can be subject to potential sampling bias and selfselection bias. Hence, this sample cannot be claimed to be as representative as random sampling, but it can certainly be used to review hypotheses (Diekmann, 2003).

\section{RESULTS OF THE EMPIRICAL STUDY}

At the beginning of the data analysis, an examination was carried out to establish any differences amongst the subjects with regard to the significance of the dependent and independent variables in the process of assessing an eWoM message. A comparison between male and female subjects using the Mann-Whitney $U$ test revealed that the variables of credibility, expertise, and simplicity of navigation on a website are significantly more important for female participants. A further comparison between young subjects ( $<35$ years, median split) and older subjects ( $\geq 35$ years) showed that much greater importance is attached to a website's visual presentation by subjects under 35 than by older test persons. According to Cohen's classification, however, all the differences in tendency identified were weak effects (Cohen, 1992), with the strength of the effect varying from 0.16 to 0.19 . In a further step, an analysis was carried out to determine any differences regarding the way a subject comes across an eWoM message in social networks. As part of this analysis, a distinction was made in the questionnaire between persons who, in the past, had been confronted with eWoM messages exclusively as the result of an active search, exclusively by receiving them passively (e.g., by seeing a recommendation on the news page of a social network), or as a result of both active searching and passive receipt. Since hardly anybody who took part in the survey specified that they had never come into contact with eWoM messages in social networks, this group was omitted from the following analyses.

With regard to credibility, expertise, homophily, topicality, information comprehensiveness, visual presentation, and navigation and structure, Kruskal-Wallis tests revealed significant differences between exclusively active participants and participants who were confronted with eWoM both actively and passively. There are also significant differences between exclusively active and exclusively passive participants for the variables of homophily, visual presentation, and information comprehensiveness. For all tendency differences, the respective variables were found to be more important among the exclusively active subjects than among the comparison groups. Subsequently, the actual hypotheses were tested using the inclusion method of multiple regression. To this end, the principle of least squares was used (Streck, 2004). Table 7 gives an overview about the regression analysis results.

TABLE 7. Multiple regression analysis-results

\begin{tabular}{|c|c|c|c|c|c|}
\hline \multicolumn{6}{|c|}{ Coefficients of the Multiple Regression } \\
\hline \multirow[t]{2}{*}{ Model } & \multicolumn{2}{|c|}{ Unstandardized Coefficients } & \multirow{2}{*}{$\begin{array}{l}\text { Standardized } \\
\text { Coefficients } \\
\mathrm{B}\end{array}$} & \multirow[t]{2}{*}{$\boldsymbol{t}$} & \multirow[t]{2}{*}{ Sig. } \\
\hline & $\boldsymbol{\beta}$ & Std. Error & & & \\
\hline Expertise & 0.225 & 0.062 & 0.211 & 3.634 & 0.000 \\
\hline Trustworthiness & 0.072 & 0.043 & 0.075 & 1.685 & 0.094 \\
\hline Homophily & 0.248 & 0.055 & 0.261 & 4.505 & 0.000 \\
\hline Sidedness & 0.011 & 0.058 & 0.009 & 0.198 & 0.844 \\
\hline Valence & -0.041 & 0.042 & -0.038 & -0.958 & 0.340 \\
\hline Relevance & 0.121 & 0.041 & 0.15 & 2.957 & 0.004 \\
\hline Topicality & 0.107 & 0.042 & 0.135 & 2.533 & 0.013 \\
\hline Information comprehensiveness & 0.168 & 0.065 & 0.167 & 2.591 & 0.011 \\
\hline Accuracy & 0.043 & 0.033 & 0.059 & 1.315 & 0.191 \\
\hline Visual presentation & 0.006 & 0.028 & 0.009 & 0.22 & 0.826 \\
\hline Navigation \& structure & 0.114 & 0.049 & 0.125 & 2.31 & 0.023 \\
\hline Social interactivity & -0.055 & 0.029 & -0.076 & -1.912 & 0.058 \\
\hline Adjusted $R^{2}$ & & & & & 0.799 \\
\hline Effect size & & & & & 1.99 \\
\hline
\end{tabular}


An $F$-test shows that the generated model is highly significant $(F(12.28)=47.349, p<0.001)$ and that a causal connection can be expected between the independent and dependent variables. Moreover, the adjusted $R^{2}$ indicates that $79.9 \%$ of the credibility variance can be ascribed to the independent variables in the model, indicating that the entire model has high explanatory power. According to Cohen (1992) classification, a strong overall effect can, therefore, be assumed. Analysis of the beta coefficients reveals that the communicator's expertise $(t=3.634, \beta=0.225, p<$ 0.001 ) and the homophily between the communicator and the recipient ( $t=4.505, \beta=0.248, p<0.001$ ) have a highly significant positive influence on credibility and that the variables' relevance ( $t=2.957, \beta=0,121, p=0.004)$, topicality $(t=2.533, \beta=0.107, p=0.013)$, information comprehensiveness ( $t=2.591, \beta=0.168, p=0.011)$, and navigation and structure $(t=2.31, \beta=0.114, p=0.023)$ have significant influence. Thus, according to results of this empirical study, the hypotheses of the effect of trustworthiness, sidedness, valence, accuracy, visual presentation, and social interactivity must be discarded at the $5 \%$ significance level. Table 8 gives an overview about the test results.

TABLE 8. Summary of results

\begin{tabular}{|c|c|c|c|}
\hline \multirow[t]{3}{*}{$\begin{array}{l}\text { Communica- } \\
\text { tor }\end{array}$} & Hla & $\begin{array}{l}\text { The greater the communicator's perceived expertise, the greater the per- } \\
\text { ceived credibility of eWoM }\end{array}$ & Confirmed \\
\hline & Hlb & $\begin{array}{l}\text { The greater the communicator's perceived trustworthiness, the higher the } \\
\text { perceived credibility of eWoM }\end{array}$ & Dismissed \\
\hline & Hlc & $\begin{array}{l}\text { The greater the perceived homophily, the greater the perceived credibility } \\
\text { of eWoM, too }\end{array}$ & Confirmed \\
\hline \multirow[t]{6}{*}{ Message } & H2a & $\begin{array}{l}\text { Two-sided eWoM messages are perceived as more credible than one-sided } \\
\text { eWoM messages }\end{array}$ & Dismissed \\
\hline & $\mathbf{H} 2 \mathrm{~b}$ & $\begin{array}{l}\text { Negative eWoM messages are perceived as more credible than positive } \\
\text { eWoM messages }\end{array}$ & Dismissed \\
\hline & H2c & $\begin{array}{l}\text { The greater the perceived relevance of an eWoM message, the greater the } \\
\text { perceived credibility of eWoM }\end{array}$ & Confirmed \\
\hline & H2d & $\begin{array}{l}\text { The greater the perceived topicality of an eWoM message, the greater the } \\
\text { perceived credibility of eWoM }\end{array}$ & Confirmed \\
\hline & H2e & $\begin{array}{l}\text { The greater the perceived accuracy of an eWoM message, the greater the } \\
\text { perceived credibility of eWoM }\end{array}$ & Dismissed \\
\hline & H2f & $\begin{array}{l}\text { The greater the perceived information comprehensiveness of an eWoM } \\
\text { message, the greater the perceived credibility of eWoM }\end{array}$ & Confirmed \\
\hline \multirow[t]{3}{*}{ Medium } & HЗа & $\begin{array}{l}\text { The better the perceived visual presentation of the medium, the greater } \\
\text { the perceived credibility of eWoM }\end{array}$ & Dismissed \\
\hline & H3b & $\begin{array}{l}\text { The greater the perceived simplicity of navigation and structure within the } \\
\text { medium, the greater the perceived credibility of eWoM }\end{array}$ & Confirmed \\
\hline & H3c & $\begin{array}{l}\text { The greater the perceived social interactivity in social networks, the } \\
\text { greater the perceived credibility of eWoM }\end{array}$ & Dismissed \\
\hline
\end{tabular}

\section{CONCLUSION}

This study showed that the communicator's influence factors in particular play a key role in the credibility assessment of eWoM. Surprisingly, trustworthiness was the only factor that failed significance. In the online context, it is often problematic for the recipient to assess the extent to which a communicator is trustworthy because less information is available due to the communicator's anonymity. Expertise, however, is easier to show in the online context by demonstrating expert knowledge or an appropriate style of language. In addition, the widely held assumption that argument quality is one of the key credibility features of an eWoM message has been largely confirmed. With regard to the medium, only the simplicity of navigation and structure was identified as a significant influence factor. Visual presentation does not seem to be particularly important in social networks, which is probably also attributable to the fact that the creative potential of a social network is much more restricted than it is on normal websites due to the net- 
work operator's standards. The connection between social interactivity and credibility as postulated in research was not verified either.

\section{LIMITATIONS AND RECOMMENDATIONS}

This empirical study is, however, subject to limitations. On one hand, the sample selection process is an arbitrary selection that cannot be said to be as representative as a random sample (Schnell et al., 1999). Hence, future research may focus on more sophisticated sampling techniques. In addition, this survey design can have problems in terms of clearly allocating a causal connection between dependent and independent variables, because all the variables were measured at the same time and there was no featuretypical time difference between cause and effect (Schnell et al., 1999). The independent variables also sometimes show increased correlations amongst each other. Multicollinearity and method distortion could be ruled out in a validity check but in the multiple regression, some variables could be 'suppressed' by others, possibly because they do not lend any additional explanatory power to the overall model (Aydemir, 2013).

Concerning practical implications, it is vital, as a first step, for companies to be able to handle existing eWoM efficiently. In this respect, it is particularly important to deliberately collect, systematise, filter, and analyse positive and negative recommen-dations, suggestions, and comments in social networks (Ismagilova et al., 2017). On this account, companies should discuss the investment in cutting-edge software solutions. In a second step, companies should help consumers to write high-quality reviews with the help of templates, which could be based on relevant and current key subjects ascertained in eWoM data analysis (M. Y. Cheung et al., 2009). Nevertheless, offering templates for higher quality reviews may give rise to the danger that consumers feel patronized. This empirical study has also specifically shown that review writers with a high level of expertise and who are socially similar to the consumer are regarded as exceptionally credible. Companies can, thereby, benefit by identifying so-called influencers or market mavens in social networks. These informed reference providers can be either well-known bloggers or individual, loyal, satisfied, and experienced consumers (Brown \& Hayes, 2008). With targeted use and the help of a bonus system, they can be prompted to regularly write positive and high-quality recommendations (M. Y. Cheung et al., 2009; Chu \& Kim, 2011). Furthermore, to exploit the effects of homophily, companies and internet platforms should ensure that potential customers are able to filter reviews by socio-demographic characteristics. Thereby, people can find product or company reviews written by people with similar background.

\section{REFERENCES}

Arndt, J. (1967). Word of mouth advertising and informal communication. In F. Cox (Ed.), Risk taking and information handling in consumer behavior. Boston, MA: Harvard Business School Press, Graduate School of Business Administration. doi:https://doi.org/10.2307/25148755

Aydemir, S. (2013). Method of multiple linear regression. VDSt Spring Conference 2013, Wolfsburg, Germany.

Bae, S., \& Lee, T. (2011). Gender differences in consumers' perception of online consumer reviews. Electronic Commerce Research, 11(2), 201-214. doi:https://doi.org/10.1007/s10660-010-9072-y

Baek, H., Ahn, J., \& Oh, S. (2014). Impact of tweets on box office revenue: Focusing on when tweets are written. ETRI Journal, 36(4), 581-590. doi:https://doi.org/10.4218/etrij.14.0113.0732

Beneke, J., Mill, J., Naidoo, K., \& Wickham, B. (2015). The impact of willingness to engage in negative electronic word-ofmouth on brand attitude: A study of airline passengers in South Africa. Journal of Business and Retail Management Research, 9(2), 68-84.

Bentele, G., \& Seidenglanz, R. (2015). Confidence and belief. In R. Fröhlich, P. Szyszka, \& G. Bentele (Eds.), Public relations manual. Berlin, Germany: Springer.

Berger, J. (2014). Word of mouth and interpersonal communication: A review and directions for future research. Journal of Consumer Psychology, 24(4), 586-607. doi:https://doi.org/10.1016/j.jcps.2014.05.002

Bhattacherjee, A., \& Sanford, C. (2006). Influence processes for information technology acceptance: An elaboration likelihood modela. MIS Quarterly, 30(4), 805-825.

Brandlmaier, E., Frank, H., Korunka, C., Plessnig, A., Schopf, C., \& Tamegger, K. (2006). Economic education of pupils of general secondary schools: Development, development of a measuring instrument, selected results (Doctoral dissertation). Webster University Vienna, Vienna, Austria. 
Brown, D., \& Hayes, N. (2008). Influencer marketing: Who really influences your customers? Amsterdam, Netherlands: Elsevier.

Bughin, J., Doogan, J., \& Vetvik, O. J. (2010). A new way to measure word-of-mouth marketing. McKinsey Quarterly, 2, 113-116.

Carbone, T. (1975). Stylistic variables as related to source credibility: A content analysis approach. Communications Monographs, 42(2), 99-106. doi:https://doi.org/10.1080/03637757509375884

Case, D. O., Johnson, J. D., Andrews, J. E., Allard, S. L., \& Kelly, K. M. (2004). From two-step flow to the internet: The changing array of sources for genetics information seeking. Journal of the American Society for Information Science and Technology, 55(8), 660-669. doi:https://doi.org/10.1002/asi.20000

Cheung, C. M., Lee, M. K., \& Rabjohn, N. (2008). The impact of electronic word-of-mouth: The adoption of online opinions in online customer communities. Internet Research, 18(3), 229-247. doi:https://doi.org/10.1108/ 10662240810883290

Cheung, C. M., \& Thadani, D. R. (2012). The impact of electronic word-of-mouth communication: A literature analysis and integrative model. Decision Support Systems, 54(1), 461-470. doi:https://doi.org/10.1016/j.dss.2012.06.008

Cheung, M. Y., Luo, C., Sia, C. L., \& Chen, H. (2007). How do people evaluate electronic word-of-mouth? informational and normative based determinants of perceived credibility of online consumer recommendations in China. In (Vol. 18). In Pacific-Asia Conference on Information Systems (PACIS), Auckland, New Zealand.

Cheung, M. Y., Luo, C., Sia, C. L., \& Chen, H. (2009). Credibility of electronic word-of-mouth: Informational and normative determinants of on-line consumer recommendations. International Journal of Electronic Commerce, 13(4), 9-38. doi: https://doi.org/10.2753/jec1086-4415130402

Chevalier, J. A., \& Mayzlin, D. (2006). The effect of word of mouth on sales: Online book reviews. Journal of Marketing Research, 43(3), 345-354. doi:https://doi.org/10.1509/jmkr.43.3.345

Chu, S.-C., \& Kim, Y. (2011). Determinants of consumer engagement in electronic Word-of-Mouth (eWOM) in social networking sites. International Journal of Advertising, 30(1), 47-75. doi:https://doi.org/10.2501/ija-30-1-047-075

Cohen, J. (1992). A power primer. Psychological Bulletin, 112(1), 155-159. doi:https://doi.org/10.1037//0033-2909.112 .1 .155

Davis, F. D. (1989). Perceived usefulness, perceived ease of use, and user acceptance of information technology. MIS Quarterly, 13(3), 319-340. doi:https://doi.org/10.2307/249008

Diekmann, A. (2003). Empirical social research. basics, methods, applications. Hamburg, Germany: Rowohlt.

Doh, S.-J., \& Hwang, J.-S. (2009). How consumers evaluate electronic Word-of-mouth (eWoM) messages. Cyber Psychology \& Behavior, 12(2), 193-197. doi:https://doi.org/10.1089/cpb.2008.0109

Eisend, M. (2003). Credibility in marketing communication: Conception, influencing factors and potential effect (1st ed.). Berlin, Germany: Springer-Verlag. doi:10.1007/978-3-322-90954-1

Eisingerich, A. B., Chun, H. H., Liu, Y., Jia, H., \& Bell, S. J. (2015). Why recommend a brand face-to-face but not on facebook? how word-of-mouth on online social sites differs from traditional word-of-mouth. Journal of Consumer Psychology, 25(1), 120-128. doi:https://doi.org/10.1016/j.jcps.2014.05.004

Fogg, B., \& Tseng, H. (1999). The elements of computer credibility. In Proceedings of the SIGCHI conference on human factors in computing systems (p. 80-87). Pittsburgh, PA: ACM. doi:https://doi.org/10.1145/302979.303001

Godes, D., \& Mayzlin, D. (2004). Using online conversations to study word-of-mouth communication. Marketing science, 23(4), 545-560.

Gröppel-Klein, A., \& Germelmann, C. C. (2009). Marketing media: Corporate communication options. Wiesbaden, Germany: Gabler Verlag.

Ha, H.-Y. (2002). The effects of consumer risk perception on pre-purchase information in online auctions: Brand, wordof-mouth, and customized information. Journal of Computer-Mediated Communication, 8(1). doi:https://doi.org/ 10.1111/j.1083-6101.2002.tb00160.x

Hajli, N. (2018). Ethical environment in the online communities by information credibility: A social media perspective. Journal of Business Ethics, 149(4), 799-810. doi:https://doi.org/10.1007/s10551-016-3036-7

Hennig-Thurau, T., Gwinner, K. P., Walsh, G., \& Gremler, D. D. (2004). Electronic word-of-mouth via consumer-opinion platforms: what motivates consumers to articulate themselves on the internet? Journal of Interactive Marketing, 
18(1), 38-52. doi:https://doi.org/10.1002/dir.10073

Hennig-Thurau, T., \& Hansen, U. (2001). Customer articulations on the internet. Betriebswirtschaft-Stuttgart, 61(5), 560-580. Hovland, C. I., \& Weiss, W. (1951). The influence of source credibility on communication effectiveness. Public Opinion Quarterly, 15(4), 635-650. doi:https://doi.org/10.1086/266350

Huang, G.-H., \& Korfiatis, N. (2015). Trying before buying: The moderating role of online reviews in trial attitude formation toward mobile applications. International Journal of Electronic Commerce, 19(4), 77-111. doi:https://doi.org/10 $.1080 / 10864415.2015 .1029359$

Huang, J.-H., \& Chen, Y.-F. (2006). Herding in online product choice. Psychology \& Marketing, 23(5), 413-428. doi:https:// doi.org/10.1002/mar.20119

Hung, K. H., \& Li, S. Y. (2007). The influence of ewom on virtual consumer communities: Social capital, consumer learning, and behavioral outcomes. Journal of Advertising Research, 47(4), 485-495. doi:https://doi.org/10.2501/ s002184990707050x

Ismagilova, E., Dwivedi, Y. K., Slade, E., \& Williams, M. D. (2017). Electronic Word of Mouth (eWOM) in the marketing context: A state of the art analysis and future directions. New York City, NY: Springer International Publishing. doi:10.1007/ 978-3-319-52459-7

Jensen, M. L., Averbeck, J. M., Zhang, Z., \& Wright, K. B. (2013). Credibility of anonymous online product reviews: A language expectancy perspective. Journal of Management Information Systems, 30(1), 293-324. doi:https://doi.org/10.2753/ mis0742-1222300109

Jeong, H.-J., \& Koo, D.-M. (2015). Combined effects of valence and attributes of e-WOM on consumer judgment for message and product: The moderating effect of brand community type. Internet Research, 25(1), 2-29. doi:https://doi.org/ 10.1108/intr-09-2013-0199

Küster, F. (2012). Two-sided messages in marketing communication. In H. H. Bauer, D. Heinrich, \& M. Samak (Eds.), Experience communication (p. 275-296). New York City, NY: Springer.

Ladhari, R., \& Michaud, M. (2015). Ewoms effects on hotel booking intentions, attitudes, trust, and website perceptions. International Journal of Hospitality Management, 46, 36-45. doi:https://doi.org/10.1016/j.ijhm.2015.01.010

Lee, M., Rodgers, S., \& Kim, M. (2009). Effects of valence and extremity of ewom on attitude toward the brand and website. Journal of Current Issues \& Research in Advertising, 31(2), 1-11. doi:https://doi.org/10.1080/10641734.2009 .10505262

Lim, Y.-s., \& Van Der Heide, B. (2014). Evaluating the wisdom of strangers: The perceived credibility of online consumer reviews on yelp. Journal of Computer-Mediated Communication, 20(1), 67-82. doi:https://doi.org/10.1111/jcc4.12093

Lin, C., Wu, Y. S., Chen, J.-C. V., et al. (2013). Electronic word-of-mouth: The moderating roles of product involvement and brand image. Proceedings of Technology Innovation and Industrial Management, Phuket, Thailand.

Lis, B. (2013). In eWOM we trust - A framework of factors that determine the eWOM credibility. Business \& Information Systems Engineering, 5(3), 129-140. doi:https://doi.org/10.1007/s12599-013-0261-9

Lis, B., \& Korchmar, S. (2012). Digital referral marketing: Conception, theories and determinants of the credibility of the Electronic Word of Mouth (EWOM). Wiesbaden, Germany: Springer Gabler.

Mackiewicz, J. (2008). Reviewer motivations, bias, and credibility in online reviews. In K. S. Amant \& S. Kelsey (Eds.), Handbook of research on computer mediated communication. Hershey, PA: IGI Global. doi:https://doi.org/10.4018/ 978-1-59904-863-5.ch020

Montoya-Weiss, M. M., Voss, G. B., \& Grewal, D. (2003). Determinants of online channel use and overall satisfaction with a relational, multichannel service provider. Journal of the Academy of Marketing Science, 31(4), 448-458. doi:https:// doi.org/10.1177/0092070303254408

Murray, K. B. (1991). A test of services marketing theory: Consumer information acquisition activities. The Journal of Marketing, 10-25. doi:https://doi.org/10.2307/1252200

Nawratil, U. (2013). Credibility in social communication. Wiesbaden, Germany: Springer-Verlag.

Nugraha, P. A., \& Indrawati. (2017). The effect of social media experiential marketing towards customers' satisfaction (A study in Chingu Korean fan cafe Bandung Indonesia). International Journal of Business and Administrative Studies, 3(2), 56-63. doi:https://doi.org/10.20469/ijbas.3.10002-2 
Oetting, M. (2010). Ripple effect: How empowered involvement drives word of mouth. |Berlin|//Heidelberg, Germany: Springer Science \& Business Media.

Ohanian, R. (1990). Construction and validation of a scale to measure celebrity endorsers' perceived expertise, trustworthiness, and attractiveness. Journal of Advertising, 19(3), 39-52. doi:https://doi.org/10.1080/00913367.1990 .10673191

Qiu, L., \& Li, D. (2010). Effects of aggregate rating on ewom acceptance: An attribution theory perspective. Pacific-Asia Conference on Information Systems PACIS, Taipei, Taiwan.

Rathore, S. (2015). Capturing, analyzing, and managing word-of-mouth in the digital marketplace. Hershey, PA: IGI Global. doi:10.4018/978-1-4666-9449-1

Reichelt, J. (2013). Information search and online word-of-mouth: An empirical analysis through discussion forums. Wiesbaden, Germany: Springer-Verlag. doi:10.1007/978-3-658-01373-8

Robinson, M. J., \& Kohut, A. (1988). Believability and the press. Public Opinion Quarterly, 52(2), 174-189. doi:https:// doi.org/10.1086/269093

Rogers, E. M. (2010). Diffusion of innovations. New York City, NY: Free Press.

Schenk, M. (2007). Media impact. Heidelberg, Germany: Mohr Siebeck.

Schnell, R., Hill, P. B., \& Esser, E. (1999). Methods of empirical social research. Munich, Germany: R. Oldenbourg Muenchen.

Steffes, E. M., \& Burgee, L. E. (2009). Social ties and online word of mouth. Internet Research, 19(1), 42-59. doi:https:// doi.org/10.1108/10662240910927812

Streck, G. (2004). Introduction to statistics: For geoecologists and other naturalists. Norderstedt, Germany: Books on Demand.

Teng, S., Wei Khong, K., Wei Goh, W., \& Yee Loong Chong, A. (2014). Examining the antecedents of persuasive eWOM messages in social media. Online Information Review, 38(6), 746-768. doi:https://doi.org/10.1108/oir-04-2014-0089

Visser, J. H. (2016). Bases of market segmentation success: A marketing decision makers perspective. International Journal of Business and Administrative Studies, 2(3), 75-80. doi:https://doi.org/10.20469/ijbas.2.10004-3

Walsh, G., \& Mitchell, V.-W. (2010). The effect of consumer confusion proneness on word of mouth, trust, and customer satisfaction. European Journal of Marketing, 44(6), 838-859. doi:https://doi.org/10.1108/30905661080001357

Wang, X., Teo, H.-H., \& Wei, K. K. (2015). Simultaneity and interactivity of the effects of communication elements on consumers'decision making in EWOM systems. Journal of Electronic Commerce Research, 16(3), 153-174.

Wathen, C. N., \& Burkell, J. (2002). Believe it or not: Factors influencing credibility on the web. Journal of the American Society for Information Science and Technology, 53(2), 134-144. doi:https://doi.org/10.1002/asi.10016

Wu, P. C., \& Wang, Y.-C. (2011). The influences of electronic word-of-mouth message appeal and message source credibility on brand attitude. Asia Pacific Journal of Marketing and Logistics, 23(4), 448-472. doi:https://doi.org/10.1108/ 13555851111165020 